\title{
Effectiveness of the Second-Stage Rehabilitation in Stroke Patients With Cognitive Impairment
}

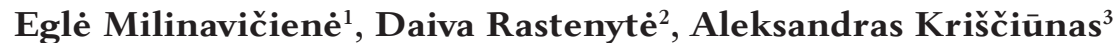 \\ ${ }^{1}$ Viršužiglis Hospital of Rehabilitation, Affiliate of Hospital of Lithuanian University of Health Sciences, \\ ${ }^{2}$ Department of Neurology, Medical Academy, Lithuanian University of Health Sciences, \\ ${ }^{3}$ Department of Rehabilitation, Medical Academy, Lithuanian University of Health Sciences, Lithuania
}

Key words: stroke; rehabilitation; functional status; cognitive impairment; predictive factors.

Summary. The aim of this study was to evaluate the recovery of functional status and effectiveness of the second-stage rehabilitation depending on the degree of cognitive impairment in stroke patients.

Material and Methods. The study sample comprised 226 stroke patients at the Viršužiglis Hospital of Rehabilitation, Hospital of Lithuanian University of Health Sciences. Functional status was evaluated with the Functional Independence Measure, cognitive function with the Mini-Mental Status Examination scale, and severity of neurologic condition with the National Institutes of Health Stroke Scale. The patients were divided into 4 study groups based on cognitive impairment: severe, moderate, mild, or no impairment.

Results. More than half (53\%) of all cases were found to have cognitive impairment, while patients with different degree of cognitive impairment were equally distributed: mild impairment (18\%), moderate impairment (17\%), and severe impairment (18\%). Improvement of functional status was observed in all study groups $(P<0.001)$. In the patients with moderate and severe cognitive impairment, cognitive recovery was significantly more expressed than in other study groups $(P<0.001)$. Insufficient recovery of functional status was significantly associated with hemiplegia $(O R, 11.15$; $P=0.015)$, urinary incontinence $(O R, 14.91 ; P<0.001)$, joint diseases $(O R, 5.52 ; P=0.022)$, heart diseases (OR, 4.10; $P=0.041)$, and severe cognitive impairment $(O R, 15.18 ; P<0.001)$, while moderate and mild cognitive impairment was not associated with the recovery of functional status.

Conclusions. During the second-stage rehabilitation of stroke patients, functional status as well as cognitive and motor skills were improved both in patients with and without cognitive impairment; however, the patients who were diagnosed with severe or moderate cognitive impairment at the beginning of second-stage rehabilitation showed worse neurological and functional status during the whole second-stage rehabilitation than the patients with mild or no cognitive impairment.

\section{Introduction}

Majority of stroke patients have motor, cognitive, and behavioral disorders during the subacute stage (1-5). Cognitive impairment is diagnosed in $21.8 \%$ to $65 \%$ of stroke patients during the subacute stage (4, 6-9) and in nearly one-third of stroke patients during the later stages of the disease (10). The literature shows that cognitive and emotional outcome in stroke patients depends on a combination of 3 factors. First, the localization of lesion in gray matter determines selective impairments. Second, diffuse neuronal dysfunction determines mental speed, memory disorders, and reduced executive functioning. Third, the degree of cognitive outcome presumably depends on such factors as patient's age, gender, premorbid level of functioning, and comorbidities. They are the objects of future research (11).

Correspondence to E. Milinavičienè, Viršužiglis Hospital of Rehabilitation, Affiliate of Hospital of Lithuanian University of Health Sciences, Pilènu 2, Sietyno vill., 53192 Kaunas distr., Lithuania. E-mail: egle.milinaviciene@kaunoklinikos.lt
Cognitive and motor impairments can influence the recovery of functional status in stroke patients during rehabilitation $(1,4,8,12-15)$, make worse the course of rehabilitation (4), extend the duration of rehabilitation $(5,14)$ as well as have a negative impact on independence in daily activities and quality of life $(4,16)$. Recently, the studies are being carried out on factors that could predict functional recovery during rehabilitation in stroke patients. Mostly they consider age, gender, type of stroke, motor disorders, and comorbidities as the factors influencing the effectiveness of rehabilitation $(1,13,14,17$, 18). However, the studies on the impact of cognitive impairment on the recovery of functional status in stroke patients are lacking. Moreover, the results on associations between cognitive impairment and effectiveness of rehabilitation are ambiguous and sometimes even contradicting.

Adresas susirašinėti: E. Milinavičienė, Lietuvos sveikatos mokslu universiteto ligoninès Kauno klinikų filialas Viršužiglio reabilitacijos ligoninè, Pilènų 2, Sietyno k., 53192 Kauno r. El. paštas: egle.milinaviciene@kaunoklinikos.lt 
The aim of our study was to evaluate the recovery of functional status and the effectiveness of the second-stage rehabilitation (subacute stage of disease) depending on the degree of cognitive impairment in stroke patients.

\section{Material and Methods}

The study included stroke patients who underwent rehabilitation at the Viršužiglis Hospital of Rehabilitation (Hospital of Lithuanian University of Health Sciences) during 2004-2007. The study was approved by the Kaunas Regional Ethics Committee for Biomedical Research. The inclusion criteria were as follows: 1) ischemic stroke, 2) hemorrhagic stroke, 3) stable health status, and 4) ability to tolerate complex measures of rehabilitation 2-3 hours daily. The exclusion criteria were the following: 1) subarachnoid hemorrhage, and 2) severe status due to comorbidities (dementia, severe heart or renal failure, serious neurological or connective tissue disorders, etc.).

Of the 302 stroke patients, 226 met the inclusion criteria. Based on the study protocol, patients' age, gender, social factors (living conditions, family status, occupation, and education), type of stroke, localization of stroke, degree of stroke, clinical symptoms, psychoemotional status, risk factors, and comorbidities were evaluated as well as functional status during the second-stage rehabilitation.

The general functional status, motor and cognitive skills, and their recovery were evaluated using the Functional Independence Measure (FIM). The scale included the motor (13 items) and cognition (5 items) subscales. The motor subscale included the following: 1) eating, 2) personal hygiene, 3) bathing, 4) dressing lower body, 5) dressing upper body, 6) toileting, 7) bladder management, 8) bowel management, 9) transfer to bed, chair, or wheelchair, 10) transfer to toilet, 11) transfer to tub or shower, 12) locomotion (walk or wheelchair), and 13) locomotion (stairs). The motor subscale ranges in score from 13 to 91 . The cognition subscale included the following: 1) comprehension, 2) expression, 3) social interaction, 4) problem solving, and 5) memory. The cognition subscale ranges in score from 5 to 35 . Altogether, the total FIM score ranges from 18 to 126. The severity of neurologic condition was estimated based on the National Institutes of Health Stroke Scale (NIHSS). The cognitive function was evaluated using the Mini-Mental Status Examination (MMSE), where orientation (time and place), attention, language, short-term memory, calculation, and complex commands are considered. This scale is a reliable, valid, and standardized measure of mental functions, which is widely used both in clinical practice and multicenter trials. The MMSE score ranges from 0 and 30 .
At the beginning of the second-stage rehabilitation, the patients were divided into 4 study groups based on cognitive function (MMSE): group 1, severe cognitive impairment (score from 0 to 10); group 2, moderate cognitive impairment (score from 11 to 20); group 3, mild cognitive impairment (score from 21 to 24), and group 4, no cognitive impairment (score from 25 to 30 ).

Based on every patient's functional status, the individually adjusted rehabilitation prog ram was set and conducted by rehabilitation team. The complex rehabilitation included medication, physical therapy (twice daily), occupational therapy, functional muscular electrostimulation, therapeutic massage, speech correction, and consultations with a psychologist, a social worker, and an orthopedist. The rehabilitation program was applied 6 days a week. The mean duration of the second-stage rehabilitation was 38.8 days (SD, 8.9); the mean time from stroke to the study beginning was 16.9 days (SD, 11.1).

The analysis included comparison of demographic and clinical data, motor and cognitive skills, and general functional status in 4 study groups. The effectiveness of rehabilitation was evaluated based on change in the FIM score during the follow-up. The effectiveness was considered insufficient if the FIM score was 18-72 (need for another person's assistance).

Similarly, age, gender, social factors (living conditions, family status, education, and occupation), clinical symptoms, psychoemotional factors, risk factors of stroke, comorbidities, type of stroke, localization of stroke, and degree of stroke were analyzed depending on functional status and recovery.

Statistical data analysis was performed using the SPSS for Windows 13.0 statistical package. For continuous variables, the mean and standard deviation (SD) were calculated. The normality of continuous variables was tested by the Kolmogorov-Smirnov test. In cases of sufficient sample and normal distribution, the comparison of means of two independent samples was evaluated by the Student $t$ test. In cases of insufficient samples $(\mathrm{n}<20)$, nonparametric variables or nonnormal distribution, the comparison of two means was evaluated by the Mann-Whitney $U$ test. Likewise, the means of two dependent samples were compared by the Student $t$ test (normal distribution) and Wilcoxon test (nonnormal distribution). Comparison of means of several groups was based on analysis of variance (ANOVA) and Fisher exact test. For comparison of qualitative variables, the chi-square test $\left(\chi^{2}\right)$ was used.

The impact of covariates on the effectiveness of rehabilitation was estimated using the univariate and multivariate logistic regression analysis, indicating the odds ratios (OR) and confidence inter- 
vals (CI). Univariate logistic regression revealed the factors (covariates) that were associated with insufficient effectiveness of rehabilitation and they were then included to multivariate logistic regression. The sets of covariates were selected for correlation based on determination coefficient $R^{2}$ and goodness of fit based on $\chi^{2}$.

The statistical significance level was set at 95\% $(P<0.05)$.

\section{Results}

The demographic and clinical characteristics of the study population are presented in Table 1. Altogether, there were 226 patients (109 men and 117 women). Cognitive impairment was documented in 120 patients $(53.1 \%)$. Among them, 41 cases $(34.2 \%)$ were found to have mild dysfunction, 39 cases $(32.5 \%)$ moderate impairment, and 40 cases (33.3\%) severe impairment. No cognitive impairment was observed in 106 patients $(46.9 \%)$. The majority $(61.5 \%)$ of study subjects were elderly patients (aged 65 years and more); the mean age of the study population was 67.8 years $(\mathrm{SD}, 10.4)$. These patients mainly suffered ischemic stroke $(88.5 \%)$.

FIM measurements revealed that the majority of patients needed a moderate or even maximal assistance of another person at the baseline (mean
FIM score, 65.9 [SD, 20.3]). At the baseline, cognitive skills measured by the FIM showed a prevailing need of moderate assistance (mean FIM score, 21.6 [SD, 7.5]). The mean MMSE score in the study sample was 20.3 (SD, 9.3). The patients with cognitive impairment were more likely to be elder $(P=0.007)$, female $(P=0.041)$, and with lower education $(P=0.002)$.

Comparison of the degree of cognitive impairment and risk factors of stroke demonstrated that the patients with moderate or severe cognitive impairment were more likely to have atrial fibrillation $(P=0.043)$ and heart failure $(P=0.015)$ as well as to be smokers $(P=0.012)$ compared with patients with mild or no cognitive impairment.

The study found that $9.7 \%$ of patients suffered a recurrent stroke. Stroke reoccurred more often in the patients with moderate or severe cognitive impairment than in the patients with mild or no cognitive impairment $(P=0.037)$. However, the data analysis showed that the type of stroke was not associated with the degree of cognitive impairment.

Lesions of the left hemisphere were significantly more often documented in the patients with severe, moderate, and mild cognitive impairment than in the patients without cognitive impairment $(87.5 \%$, $53.8 \%, 48.8 \%$, and $32.1 \%$, respectively; $P<0.001$ ).

Table 1. Characteristics of Patients by Degree of Cognitive Dysfunction ( $\mathrm{n}=226)$

\begin{tabular}{|c|c|c|c|c|c|}
\hline Characteristic & $\begin{array}{l}\text { Normal } \\
(\mathrm{n}=106)\end{array}$ & $\begin{array}{c}\text { Mild } \\
(\mathrm{n}=41)\end{array}$ & $\begin{array}{l}\text { Moderate } \\
(\mathrm{n}=39)\end{array}$ & $\begin{array}{l}\text { Severe } \\
(\mathrm{n}=40)\end{array}$ & $P$ \\
\hline Age, mean (SD), years & $65.5(9.6)$ & $68.3(12.7)$ & $71.7(8.4)$ & $69.2(10.5)$ & 0.007 \\
\hline $\begin{array}{l}\text { Gender } \\
\text { Male } \\
\text { Female }\end{array}$ & $\begin{array}{l}60(56.6) \\
46(43.4) \\
\end{array}$ & $\begin{array}{l}20(48.8) \\
21(51.2) \\
\end{array}$ & $\begin{array}{l}12(30.8) \\
27(69.2) \\
\end{array}$ & $\begin{array}{l}17(42.5) \\
23(57.5) \\
\end{array}$ & 0.041 \\
\hline $\begin{array}{l}\text { Living conditions } \\
\text { Not single } \\
\text { Single }\end{array}$ & $\begin{array}{l}63(59.4) \\
43(40.6) \\
\end{array}$ & $\begin{array}{l}20(48.8) \\
21(51.2) \\
\end{array}$ & $\begin{array}{l}18(46.2) \\
21(53.8) \\
\end{array}$ & $\begin{array}{l}20(50.0) \\
20(50.0) \\
\end{array}$ & 0.406 \\
\hline $\begin{array}{l}\text { Education } \\
\text { Professional College / Higher } \\
\text { Secondary } \\
\text { Primary } \\
\end{array}$ & $\begin{array}{l}21(19.8) \\
64(60.4) \\
21(19.8)\end{array}$ & $\begin{array}{c}4(9.8) \\
17(41.5) \\
20(48.8)\end{array}$ & $\begin{array}{c}2(5.1) \\
20(51.3) \\
17(43.6)\end{array}$ & $\begin{array}{l}4(10.0) \\
17(42.5) \\
19(47.5)\end{array}$ & 0.002 \\
\hline $\begin{array}{l}\text { Risk factors } \\
\text { Arterial hypertension } \\
\text { Ischemic heart disease or myocardial infarction } \\
\text { Heart failure } \\
\text { Atrial fibrillation } \\
\text { Diabetes mellitus } \\
\text { Smoking }\end{array}$ & $\begin{array}{l}83(78.7) \\
60(56.6) \\
56(52.8) \\
22(20.8) \\
12(11.3) \\
20(18.8)\end{array}$ & $\begin{array}{c}36(87.8) \\
22(53.7) \\
20(48.8) \\
8(19.5) \\
2(4.9) \\
9(22.0)\end{array}$ & $\begin{array}{c}31(79.5) \\
26(66.7) \\
24(61.5) \\
15(38.5) \\
7(17.9) \\
12(30.8)\end{array}$ & $\begin{array}{c}34(85.5) \\
27(67.5) \\
26(65.1) \\
15(37.5) \\
2(5.0) \\
11(27.5) \\
\end{array}$ & $\begin{array}{l}0.175 \\
0.416 \\
\mathbf{0 . 0 1 5} \\
\mathbf{0 . 0 4 3} \\
0.160 \\
0.012 \\
\end{array}$ \\
\hline Recurrent stroke & $5(4.7)$ & $5(12.2)$ & $8(20.5)$ & $4(10.8)$ & 0.037 \\
\hline $\begin{array}{l}\text { Type of stroke } \\
\text { Ischemic } \\
\text { Hemorrhagic }\end{array}$ & $\begin{array}{l}92(86.8) \\
14(13.2)\end{array}$ & $\begin{array}{c}35(85.4) \\
6(14.6)\end{array}$ & $\begin{array}{c}36(92.3) \\
3(7.7)\end{array}$ & $\begin{array}{c}37(92.5) \\
3(7.5)\end{array}$ & 0.597 \\
\hline $\begin{array}{l}\text { Localization of lesion } \\
\text { Right hemisphere } \\
\text { Left hemisphere } \\
\text { Other }\end{array}$ & $\begin{array}{c}63(59.4) \\
34(32.1) \\
9(8.5)\end{array}$ & $\begin{array}{l}15(36.6) \\
20(48.8) \\
6(14.6)\end{array}$ & $\begin{array}{l}13(33.3) \\
21(53.8) \\
5(12.8)\end{array}$ & $\begin{aligned} & 3(7.5) \\
35 & (87.5) \\
2 & (5.0)\end{aligned}$ & $<0.001$ \\
\hline
\end{tabular}

Values are number (percentage) unless otherwise indicated. 
The analysis of stroke symptoms and neurological status revealed that the patients with poor neurological status more frequently had worse cognitive impairment $(P=0.001)$. Moreover, the patients with cognitive impairment were significantly more likely to suffer urinary incontinence $(P<0.001)$, unilateral neglect syndrome $(P=0.001)$, and depression $(P=0.001)$ (Table 2).

The recovery of patients' functional status during the second-stage rehabilitation depending on the degree of cognitive impairment is presented in Table 3. At the baseline, poorer cognitive impairment was significantly associated with poorer general functional status as well as poorer cognitive and motor skills $(P<0.001)$. Nevertheless, during the second-stage rehabilitation, all these features - general functional status, motor skills, and cognitive skills - showed an improvement as measured by the FIM $(P<0.001)$.

The changes in general functional status, motor skills, and cognitive skills as of FIM were similar in all 4 study groups. However, the patients with severe and moderate cognitive impairment showed a significantly greater improvement in cognitive skills than those with with mild or no cognitive impairment $(P<0.001)$.

The multivariate logistic regression analysis demonstrated that insufficient recovery of general functional status as measured by the FIM was more likely to occur in the patients with hemiplegia (OR, 11.15; $P=0.015)$, urinary incontinence (OR, 14.91; $P<0.001$ ), joint diseases (OR, 5.52; $P=0.022)$, and heart diseases (OR, 4.10; $P=0.041)$, and severe cognitive impairment (OR, 15.18; $P<0.001)$ (Table 4). Meanwhile, mild and moderate cognitive impairment as well as localization of lesion, dysphagia, hemiparesis, and unilateral neglect syndrome did not have a negative impact on the recovery of functional status during the second-stage rehabilitation.

\section{Discussion}

Our study is one of the first studies evaluating the effectiveness of rehabilitation depending on the degree of cognitive impairment. The impact of cognitive impairment on the improvement of general functional state, motor skills, and cognitive skills in stroke patients as well as factors predicting the recovery during the second-stage rehabilitation have been identified.

Previous literature shows that cognitive impairment mainly manifests in disorders of orientation, memory, attention, perception, and language (8, 19-21), and it has a negative impact on daily activities and patient's independence level $(3,4,12-14$, 22) and increases the prevalence of depression (9). Our study demonstrated that at the beginning of the

Table 2. Clinical Characteristics and Degree of Cognitive Dysfunction ( $\mathrm{n}=226)$

\begin{tabular}{|c|c|c|c|c|c|}
\hline Characteristic & $\begin{array}{l}\text { Normal } \\
(\mathrm{n}=106)\end{array}$ & $\begin{array}{c}\text { Mild } \\
(\mathrm{n}=41)\end{array}$ & $\begin{array}{c}\text { Moderate } \\
(\mathrm{n}=39)\end{array}$ & $\begin{array}{l}\text { Severe } \\
(\mathrm{n}=40)\end{array}$ & $P$ \\
\hline Neurological state (NIHSS), mean (SD), score & $6.7(3.3)$ & $6.9(3.6)$ & $7.6(4.7)$ & $11.2(4.5)$ & 0.001 \\
\hline MMSE, mean (SD), score & $27.3(1.5)$ & $22.8(1.1)$ & $16.5(2.8)$ & $2.8(4.1)$ & $<0.001$ \\
\hline $\begin{array}{l}\text { Clinical symptoms } \\
\text { Motor aphasia } \\
\text { Sensory aphasia } \\
\text { Unilateral neglect syndrome } \\
\text { Urinary incontinence } \\
\text { Depression }(\mathrm{n}=193)\end{array}$ & $\begin{array}{c}15(14.2) \\
2(1.9) \\
3(2.8) \\
11(10.4) \\
29(27.6)\end{array}$ & $\begin{array}{c}16(39.0) \\
2(4.9) \\
1(4.8) \\
9(22.0) \\
8(19.5)\end{array}$ & $\begin{array}{c}20(51.3) \\
12(30.8) \\
4(10.2) \\
12(30.8) \\
17(56.7)\end{array}$ & $\begin{array}{c}34(85.0) \\
31(66.0) \\
5(12.5) \\
19(47.5) \\
23(57.5)\end{array}$ & $\begin{array}{c}<0.001 \\
<0.001 \\
0.001 \\
<0.001 \\
0.001\end{array}$ \\
\hline
\end{tabular}

Values are number (percentage) unless otherwise indicated.

Table 3. Recovery of Functional Status During the Second-Stage Rehabilitation and Degree of Cognitive Dysfunction $(n=226)$

\begin{tabular}{|c|c|c|c|c|c|}
\hline & $\begin{array}{l}\text { Normal } \\
(\mathrm{n}=106)\end{array}$ & $\begin{array}{l}\text { Mild } \\
(n=41)\end{array}$ & $\begin{array}{l}\text { Moderate } \\
\quad(n=39)\end{array}$ & $\begin{array}{l}\text { Severe } \\
(n=40)\end{array}$ & $P$ \\
\hline \multicolumn{6}{|l|}{ FIM at baseline } \\
\hline Total score & $75.1(17.3)$ & $68.6(16.7)$ & $61.2(17.3)$ & $43.6(14.9)$ & 0.001 \\
\hline Motor subscale & $48.2(15.1)$ & $45.6(14.4)$ & $42.5(14.8)$ & $34.1(13.7)$ & 0.001 \\
\hline Cognition subscale & $26.8(3.8)$ & $22.9(3.6)$ & $18.7(4.3)$ & $9.5(4.3)$ & 0.001 \\
\hline \multicolumn{6}{|l|}{ FIM change } \\
\hline Total score & $27.4(8.8)$ & $29.5(1.4)$ & $26.1(7.5)$ & $27.6(9.9)$ & 0.576 \\
\hline Motor subscale & $24.1(8.1)$ & $24.8(8.7)$ & $21.5(6.8)$ & $24.1(8.9)$ & 0.320 \\
\hline Cognition subscale & $3.7(1.8)$ & $3.3(2.3)$ & $4.7(1.9)$ & $5.4(2.2)$ & 0.001 \\
\hline
\end{tabular}

Values are number (standard deviation). 
Table 4. Predictive Value of Factors Associated With Insufficient Recovery of General Functional Status (Multivariate Logistic Regression Analysis)

\begin{tabular}{lcccc}
\hline \multicolumn{1}{c}{ Factor } & $\beta$ & OR & $95 \%$ CI & $P$ \\
\hline Age, years & -0.048 & 0.92 & $0.90-0.96$ & $<\mathbf{0 . 0 0 1}$ \\
\hline Heart diseases (yes/no) & 1.412 & 4.10 & $1.01-16.75$ & $\mathbf{0 . 0 4 1}$ \\
\hline Joint diseases (yes/no) & 1.708 & 5.52 & $1.27-23.86$ & $\mathbf{0 . 0 2 2}$ \\
\hline Localization of lesion & & & & \\
$\quad$ Right hemisphere & -0.457 & 1.0 & 0.481 \\
$\quad$ Left hemisphere & -0.653 & 0.633 & 0.583 \\
$\quad$ Other & & & $0.17-2.25$ & \\
\hline Motor function disorder in extremities & -0.240 & 1.0 & $0.05-5.36$ & 0.769 \\
$\quad$ No & 2.412 & 11.15 & & $\mathbf{0 . 0 1 5}$ \\
$\quad$ Hemiparesis & & & \\
$\quad$ Hemiplegia & 0.305 & 1.0 & $1.15-107.98$ & \\
\hline Cognitive dysfunction & 0.768 & 2.15 & $0.23-7.91$ & 0.735 \\
$\quad$ No & 2724 & 15.18 & $0.42-11.04$ & 0.357 \\
$\quad$ Mild & 1.495 & 4.45 & $0.46-48.29$ & 0.194 \\
$\quad$ Sederate & 0.612 & 1.84 & $0.21-15.97$ & 0.578 \\
\hline Unilateral neglect syndrome (yes/no) & 2.702 & 14.91 & $4.60-48.29$ & $<\mathbf{0 . 0 0 1}$ \\
\hline Dysphagia (yes/no) & & &
\end{tabular}

$\beta$, logistic regression coefficient; OR, odds ratio; CI, confidence interval.

second-stage rehabilitation, more than half $(53.1 \%)$ of patients had cognitive impairment: motor aphasia $(37.6 \%)$, sensory aphasia $(20.8 \%)$, orientation disorders (31.4\%), and memory disorders (40.9\%). Additionally, depression was diagnosed in $29 \%$ of patients.

Several studies analyzing the associations between neurological status or functional status and the degree of cognitive impairment have been carried out $(12,23)$. Rabadi et al. evaluated the influence of cognitive impairment on the effectiveness of rehabilitation in stroke patients and found that the patients with cognitive impairment had a significantly worse neurological and general functional status at the beginning of rehabilitation, though the researchers did not find any association between cognitive function and motor function impairments (3). Some other studies did not find any association between cognitive and motor function impairments either $(4,15)$. Paolucci et al. aimed to evaluate the influence of aphasia on the effectiveness of rehabilitation in stroke patients and noted that the patients with language and perception disorders had a significantly worse neurological and general functional status at the beginning of rehabilitation and had worse recovery of functional status and mobility during the rehabilitation compared with the patients with no language and perception disorders or only with language disorders (21). Wee et al. found that aphasia and other cognitive impairments correlated with the lower FIM scores at discharge after in-patient rehabilitation (14). Other researchers found that the duration of rehabilitation in the patients with no cognitive impairment was shorter and they were more likely to be discharged from hospital compared with the patients with diagnosed cognitive impairment (3). Our study showed that the patients with moderate or severe cognitive impairment at the beginning of the second-stage rehabilitation had a worse neurological and general functional status throughout the whole study compared with the patients with mild or no cognitive impairment at the baseline. The results of our study together with the results from other studies showed that the patients with severe or moderate cognitive impairment had a significantly better progress of cognitive function during the second-stage rehabilitation compared with the patients with mild or no cognitive impairment.

There are published studies that analyzed the impact of cognitive impairment on functional status improvement in stroke patients and provided ambiguous results. Rabadi et al. conducted the study aiming to establish whether the rehabilitation was effective in stroke patients with cognitive impairment. They surveyed 668 patients during the rehabilitation and revealed that general functional status measured by the FIM improved significantly regardless of the degree of cognitive impairment; additionally, they did not find significant differences in improvement between patients with and without cognitive impairment (3). Heruti et al. also noted that the degree of cognitive impairment did not influence the change of functional status during the rehabilitation (12). Saksena et al. investi- 
gated the impact of cognition and depression on functional status and its recovery after 6 months in stroke patients and found that better improvement and recovery of functional status was significantly influenced by less expressed depression and its alleviation, neurological status and its improvement, better functional status and younger age at onset, but not by cognitive function or its change (24). Hama et al. analyzed the impact of depression and apathy on the recovery of functional status and found that the MMSE score and Apathy scale score were negatively associated with the improvement of functional status during the rehabilitation in stroke patients, while there were no associations between depression and function status (22). Zinn et al. conducted a prospective cohort study aiming to evaluate the association between cognitive impairment and recovery of functional status and found that the patients who suffered cognitive impairment had poorer recovery of daily activities 6 months following the rehabilitation as measured by the Lawton test (4). Our results demonstrate that the patients with cognitive impairment experience a significant improvement in general functional status and motor skills during the second-stage rehabilitation similarly like the patients without cognitive impairment. Moreover, both general functional status and motor skills measured by the FIM improved during the second-stage rehabilitation to similar extent in all study groups (regardless of the degree of cognitive dysfunction).

There are ambiguous results in the literature about the impact of cognitive function on functional status outcomes in stroke patients. Heruti et al. studied the recovery of functional status in elderly patients and found that poorer recovery of motor skills and general functional status measured by the FIM were influenced by cognitive impairment diagnosed at the beginning of rehabilitation (12). Zinn et al. revealed that cognitive impairment increased the likelihood of insufficient functional status recovery 4 -fold, while the association of cognitive impairment with insufficient recovery of motor skills was not significant (4). In contrast, Meijer et al. investigated various factors and their impact on the recovery of functional status during the subacute stage of stroke and found that cognitive impairment was the main factor predicting poor outcomes of stroke (25). Paolucci et al. pointed that language and perception disorder was a significant predictive factor for the effectiveness of rehabilitation, since it increased the likelihood of poor recovery of functional status 4-fold (21). Other researchers note that aphasia as a significant disorder of cognitive function has also an impact on the recovery of functional status in stroke patients and leads to poorer disease outcomes $(14,21,26,27)$. Ones et al. investigated the associations between age, gender, diabetes, primary functional status, cognitive functions, degree of motor dysfunction, spasticity at the beginning of rehabilitation, and functional status at the end of rehabilitation. They found that the recovery of general functional status and motor skills measured by FIM were associated with age, spasticity, functional status, cognitive function, and motor skills at start of rehabilitation, but gender and diabetes were not associated with functional status after rehabilitation (1). Oksala et al. conducted the study analyzing the long-term survival in stroke patients depending on cognitive impairment. The analysis of 12-year follow-up showed that impairments in executive functions, language, memory, and visuospatial/constructional skills were associated with poorer disease outcomes (8). Paker et al. analyzed the impact of cognitive impairment on the recovery of functional status measured by the Barthel index in stroke patients and found that rehabilitation was effective in subacute stroke patients both with and without cognitive impairment (23).

Our multivariate logistic regression revealed that insufficient general functional status was more likely to be documented in patients with hemiplegia, urinary incontinence, joint diseases, heart diseases, and severe cognitive impairment. Meanwhile, mild or moderate cognitive impairment was shown to have no significant predictive value on insufficient recovery of general functional status and motor skills during the second-stage rehabilitation. The discrepancy between our results and results from the previous studies could be explained by sample differences in age distribution, disease duration until rehabilitation, degree of cognitive impairment, degree of neurological and functional status at the beginning of rehabilitation as well as differences in evaluation criteria and methods for effectiveness.

\section{Conclusions}

During the second-stage rehabilitation, functional status as well as cognitive and motor skills improved both in stroke patients with and without cognitive impairment; however, the patients who were diagnosed with severe or moderate cognitive impairment at the beginning of second-stage rehabilitation showed worse neurological and functional status during the whole second-stage rehabilitation than the patients with mild or no cognitive impairment. The insufficient recovery of functional status during the second-stage rehabilitation in stroke patients was found to be influenced by hemiplegia, urinary incontinence, joint diseases, heart diseases, and severe cognitive impairment, while the moderate and mild cognitive impairment did not have such a negative impact on the recovery of functional status.

\section{Statement of Conflict of Interest}

The authors state no conflict of interest. 


\title{
Sergančiųjų galvos smegenų insultu reabilitacijos veiksmingumas antruoju reabilitacijos etapu esant pažinimo funkcijų sutrikimams
}

\author{
Eglè Milinavičiene் $\dot{e}^{1}$, Daiva Rastenyt $\dot{e}^{2}$, Aleksandras Kriščiūnas ${ }^{3}$ \\ ${ }^{1}$ Lietuvos sveikatos mokslų universiteto Kauno kliniku filialas Viršužiglio reabilitacijos ligonine, \\ ${ }^{2}$ Lietuvos sveikatos mokslu universiteto Medicinos akademijos Neurologijos klinika, \\ ${ }^{3}$ Lietuvos sveikatos mokslu universiteto Medicinos akademijos Reabilitacijos klinika
}

Raktažodžiai: galvos smegenų insultas, reabilitacija, funkcinė būklė, pažinimo funkcijų sutrikimas, prognoziniai veiksniai.

Santrauka. Tyrimo tikslas. Iૃvertinti sergančiųju galvos smegenų insultu funkcinès būklès atsigavimą ir reabilitacijos veiksmingumą antruoju reabilitacijos etapu priklausomai nuo pažinimo funkciju sutrikimo sunkumo.

Tirtuju kontingentas ir tyrimo metodai. Tirti 226 ligoniai, patyrę galvos smegenų insultą, kuriems reabilitacija antruoju reabilitacijos etapu buvo Lietuvos sveikatos mokslu universiteto ligoninès Kauno klinikų filialo Viršužiglio reabilitacijos ligoninèje.

Ligonių funkcinẻ būklẻ vertinta pagal funkcinio nepriklausomumo testą; pažinimo funkcijos - pagal trumpą protinès būklès tyrimo testą, insulto sunkumas vertintas pagal nacionalinių sveikatos institutų insulto skalę. Ligoniai reabilitacijos pradžioje priklausomai nuo pažinimo funkcijų sutrikimo sunkumo buvo suskirstyti i keturias grupes: sunkus, vidutinis, lengvas pažinimo funkcijų sutrikimas, nėra pažinimo funkcijų sutrikimo.

Rezultatai. Pažinimo funkcijų sutrikimas nustatytas 53,1 proc. ligonių. Iš jų lengvas pažinimo funkciju sutrikimas nustatytas 18 proc., vidutinis -17 proc., sunkus - 33,3 proc. ligonių. Antruoju reabilitacijos etapu visose tiriamųju grupèse konstatuotas funkcinès būklès gerejjimas $(\mathrm{p}<0,001)$. Ligoniams, kuriems buvo nustatytas vidutinis arba sunkus pažinimo funkcijų sutrikimas, nustatytas didesnis pažinimo funkciju kitimas lyginant su kitų tiriamųju grupių ligoniais $(\mathrm{p}<0,001)$. Nepakankamam funkcinès būklès atsigavimui itakos turèjo hemiplegija ( $\mathrm{S} S=11,15 ; \mathrm{p}=0,015)$; šlapimo nelaikymas ( $\breve{S} \mathrm{~S}=14,91 ; \mathrm{p}<0,001$ ); sąnarių $(\breve{S} S=5,52 ; p=0,022)$; širdies ligos ( $\breve{S} S=4,10 ; p=0,041)$; sunkus pažinimo funkciju sutrikimas $(\check{S} S=15,18$; $\mathrm{p}<0,001)$, o lengvas ir vidutinio sunkumo pažinimo funkcijų sutrikimas įtakos neturejjo.

Išvados. Antruoju reabilitacijos etapu ligonių, patyrusių galvos smegenų insultą funkcinè būklè bei gebejjimai, priklausomi nuo motorikos ir pažinimo funkcijų, gerèjo visose tiriamųjų grupèse, tačiau ligoniams, kuriems buvo nustatytas vidutinis arba sunkus pažinimo funkcijų sutrikimas, konstatuota sunkesnè neurologinè ir funkcinè būklè reabilitacijos metu lyginant su ligoniais, kuriems buvo lengvas pažinimo funkciju sutrikimas ar pažinimo funkcijos nebuvo sutrikusios.

\section{References}

1. Ones K, Yalcinkaya EY, Toklu BC, Caglar N. Effects of age, gender, and cognitive, functional and motor status on functional outcomes of stroke rehabilitation. Neurorehabilitation 2009;25:241-9.

2. Skidmore ER, Whyte EM, Holm MB, Becker JT, Butters MA, Dew MA, et al. Cognitive and affective predictors of rehabilitation participation after stroke. Arch Phys Med Rehabil 2010;91:203-7.

3. Rabadi MH, Rabadi FM, Edelstein L, Peterson M. Cognitively impaired stroke patients do benefit from admission to an acute rehabilitation unit. Arch Phys Med Rehabil 2008; 89:441-8.

4. Zinn S, Dudley TK, Bosworth HB, Hoenig HM, Duncan PW, Horner RD. The effect of poststroke cognitive impairment on rehabilitation process and functional outcome. Arch Phys Med Rehabil 2004;85:1084-90.

5. Kenneth NK, Chetwyn CH, Derrick KS. Relationship of motor and cognitive abilities to functional performance in stroke rehabilitation. Brain Injury 2001;15:443-53.

6. Tang WK, Chan SSM, Chiu HFK, Ungvari GS, Wong KS, Kwok TCY, et al. Frequency and clinical determinants of poststroke cognitive impairment in nondemented stroke patients. J Geriatr Psychiatry Neurol 2006;19:65-71.

7. Fernández-Concepción O, Rojas-Fuentes I, Pando A, Marrero-Fleita M, Mesa-Barrero Y, Santiesteban-Velázquez N, et al. Cognitive deterioration following cerebral infarction: frequency and determining factors. Rev Neurol 2008;46:
326-30.

8. Oksala NK, Jokinen H, Melkas S, Oksala A, Pohjasvaara $\mathrm{T}$, Hietanen $\mathrm{M}$, et al. Cognitive impairment predicts poststroke death in long-term follow-up. I Neurol Neurosurg Psychiatry 2009;80:1230-5.

9. Jaillard A, Grand S, Le Bas JF, Hommel M. Predicting cognitive dysfunctioning in nondemented patients early after stroke. Cerebrovasc Dis 2010;29:415-23.

10. Patel MD, Coshall C, Rudd AG, Wolfe CD. Cognitive impairment after stroke: clinical determinants and its associations with long-term stroke outcomes. I Am Geriatr Soc 2002;50:700-6.

11. de Haan EH, Nys GM, Van Zandvoort MJ. Cognitive function following stroke and vascular cognitive impairment. Curr Opin Neurol 2006;19:559-64.

12. Heruti RJ, Lusky A, Dankner R, Ring H, Dolgopiat M, Barell V, et al. Rehabilitation outcome of elderly patients after a first stroke: effect of cognitive status at admission on the functional outcome. Arch Phys Med Rehabil 2002;83: 742-9.

13. Kelly PJ, Furie KL, Shafqat S, Rallis N, Chang Y, Stein J. Functional recovery following rehabilitation after hemorrhagic and ischemic stroke. Arch Phys Med Rehabil 2003;84:968-72.

14. Wee JYM, Hopman WM. Stroke impairment predictors of discharge function, length of stay, and discharge destination in stroke rehabilitation. Am J Phys Med Rehabil 
2005;84:604-12.

15. Nas K, Gur A, Cevik R, Sarac AJ. The relationship between physical impairment and disability during stroke rehabilitation: effect of cognitive status. Int J Rehabil Res 2004;27:181-4.

16. Krančiukaitė-Butylkinienè D, Rastenytė D, Jurėnienė K, Jančaitytė L. Physical and mental health of stroke survivors and their daily activities. Medicina (Kaunas) 2009;45:896903.

17. Luk JK, Cheung RT, Ho SL, Li L. Does age predict outcome in stroke rehabilitation? A study of 878 Chinese subjects. Cerebrovasc Dis 2006;21:229-34.

18. Sharma JC, Fletcher S, Vassallo M, Ross I. Cardiovascular disease and outcome of acute stroke: influence of pre-existing cardiac failure. Eur J Heart Fail 2000;2:145-50.

19. Zinn S, Bosworth HB, Hoenig HM, Swartzwelder HS. Executive function deficits in acute stroke. Arch Phys Med Rehabil 2007;88:173-80.

20. Hochstenbach JB, den Otter R, Mulder TW. Cognitive recovery after stroke: a 2-year follow-up. Arch Phys Med Rehabil 2003;84:1499-504.

21. Paolucci S, Matano A, Bragoni M, Coiro P, De Angelis D, Fusco FR, et al. Rehabilitation of left brain-damaged ischemic stroke patients: the role of comprehension language deficits. A matched comparison. Cerebrovasc Dis 2005;20: 400-6.

22. Hama S, Yamashita H, Shigenobu M, Watanabe A, Hiramoto K, Kurisu K, et al. Depression or apathy and functional recovery after stroke. Int J Geriatr Psychiatry 2007;22: 1046-51.

23. Paker N, Buğdaycı D, Tekdöş D, Kaya B, Dere C. Impact of cognitive impairment on functional outcome in stroke. Stroke Res Treat 2010;11.

24. Saxena SK, Ng TP, Koh G, Yong D, Fong NP. Is improvement in impaired cognition and depressive symptoms in post-stroke patients associated with recovery in activities of daily living? Acta Neurol Scand 2007;115:339-46.

25. Meijer R, Ihnenfeldt DS, Limbeek van J, Vermeulen M, Haan de RJ. Prognostic factors in the subacute phase after stroke for the future residence after six months to one year. A systematic review of the literature. Clin Rehabil 2003; 17:512-20.

26. Shen Q, Cordato D, Chan DK, Hung WT, Karr M. Identifying the determinants of 1-year post-stroke outcomes in elderly patients. Acta Neurol Scand 2006;113:114-20.

27. Tur BS, Gursel YK, Yavuzer G, Kucukdeveci A, Arasil T. Rehabilitation outcome of Turkish stroke patients: in a team approach setting. Int J Rehabil Res 2003;26:271-7.

Received 1 September 2011, accepted 30 September 2011 Straipsnis gautas 201109 01, priimtas 20110930 